\title{
DESA ADAT SEBAGAI PELAKU USAHA PERTAMBANGAN BAHAN GALIAN GOLONGAN C (STUDI DI DESA ADAT BADEG)
}

\author{
Putu Ulandari Sri Lestari, Fakultas Hukum Universitas Udayana, e-mail: \\ ulandarilestari@gmail.com \\ I Gede Pasek Pramana, Fakultas Hukum Universitas Udayana, e-mail: \\ pasekpramana@gmail.com
}

doi: https://doi.org/10.24843/KS.2020.v08.i11.p04

\begin{abstract}
ABSTRAK
Penulisan artikel ini bertujuan untuk mengetahui legalitas yang dimiliki desa adat untuk bertindak sebagai pelaku usaha pertambangan galian C serta kedudukan Hukum Desa adat yang melakukan usaha pertambangan diatas tanah Druwe Desa, sebagaimana dijelaskan desa adat merupakan merupakan kesatuan masyarakat yang memiliki kedudukan yang dapat menjalankan dan melaksanakan kebijakan lingkungan wilayahnya, sehingga dapat melaksanakan melaksanakan urusan dan kepentingan masyarakat setempat dalam kegiatan usaha pertambangan galian C di Desa Adat Badeg. Meninjau permasalahan di atas maka metode yang digunakan ialah penelitian socio-legal merupakan sebuah studi penelitian yang melihat hukum melalui penggabungan antara analisa normatif dan pendekatan ilmu non-hukum, bertujuan untuk mengidentifikasi hukum sebagai institusi sosial yang riil dan fungsional dalam sistem kehidupan danmemperoleh pengetahuan hukum secara empiris dengan terjun langsung ke obyek penelitian yaitu mengetahui bagaimana keadaan lapangan menegenai usaha pertambangan galian C pada Desa Adat Badeg, dengan analisa normatif yang meneliti melalui bahan berupa buku, jurnal dan peraturan perundang-undangan, sedangkan dengan analisa empiris yakni data yang diperoleh langsung dari masyarakat berupa wawancara. Pengelolahan tanah padruwen desa yang dijadikan pertambangan galian C merupakan tanah diperoleh berdasarkan metinin yang dilakukan oleh Desa Adat kepada masyarakat adat, tanah tersebut dapat dipergunakan untuk menunjang sektor perekonomian, sebagaimana pekerjaan masyarakat adat adalah menggarap tanah metinin menjadi pertambangan galian $C$ sesuai dengan UU MINERBA dan menggunakan bahan galian yang ditegaskan dalam PP Nomor 26 Tahun 2012.
\end{abstract}

\section{Kata Kunci: Desa Adat, Metinin, Pertambangan Galian C}

\begin{abstract}
The writing of this article to find out and analyze the legality of the Traditional Village to act as a mining business actor for mining materials $C$ on the Druwe Village land, and to know and analyze the legal position of the Badeg Traditional Village in you by mining $C$ minerals on druwe land. The village, as explained by the customary village, is a community unit that has a position that can carry out and implement the environmental policy of its territory, so that it can carry out the affairs and interests of the local community in the $C$ excavation mining business activities in the Badeg Traditional Village. Reviewing the above problems, the method used is socio-legal research, which is a research study that looks at law through a combination of normative analysis and non-legal scientific approaches, aims to identify law as a real and functional social institution in a living system and obtain empirical legal knowledge. by going directly to the object of research, namely knowing how the state of the field regarding the $C$ mining business in Badeg Traditional Village, with normative analysis that examines through materials in the form of books, journals and statutory regulations, while with empirical analysis, namely data obtained
\end{abstract}


directly from the community in the form of Interview. The management of the village padruwen land which is used as an excavation C mining is land obtained based on metinine carried out by the Traditional Village to the customary community, the land can be used to support the economic sector, as the work of the customary community is to cultivate metinine land into quarry mining $C$ in accordance with the MINERBA Law and use minerals that are confirmed in Government Regulation Number 26 of 2012.

\section{Keywords: Desa Adat, Metinin, Excavation Mining C}

\section{Pendahuluan}

\subsection{Latar Belakang}

Bali tidak hanya penuh dengan kekayaan budaya tetapi juga kaya dengan kekayaan alam, salah satunya kekayaan non-logam berupayang berada di wilayah timur Pulau Bali, Kabupaten Karangasem. Kabupaten Karangasem selain memiliki Gunung Agung yang terkenal menjadi tempat yang sakral dikenal juga menyumbang hasil bumi berupa kekayaan non-logam. Kekayaan alam non-logam termasuk bahan galian berupa tambang yang mencakup pasir. Kekayaan alam, bumi dan air yang dimiliki oleh Indonesia didalamnya dapat dikuasai oleh negara dan dipergunakan untuk kemakmuran rakyat, sebagaimana isi Pasal 33 ayat 3 Undang-Undang Dasar 1945. Mengingat pasir salah satu hasil alam/ kekayaan alam yang terkandung didalam bumi yang pengelolaannya dilakukan seoptimal dan seefesienmungkin serta dimanfaat yang sebagaimana mestinya bagi kesejahteraan rakyat secara berkelanjutan.

Sukandarrumidi menyatakan pertambangan merupakan seluruh usaha yang dilakukan oleh seseorang atau badan usaha untuk mengambil bahan galian dengan tujuan dimanfaatkan selanjutnya untuk kepentingan manusia. ${ }^{1}$ Penjelasan mengenai pengertian pertambangan memberikan pemahaman tentang aktivitas pertambangan dalam arti luas, yaitu keseluruhan kegiatan, sejak prapenambangan sampai proses dan pasca penambangan. ${ }^{2}$ Mendasarkan pada istilah Hukum, hukum pertambangan merupakan terjemahan dari bahasa Inggris, yaitu mining law. Salim HS mengemukakan bahwa hukum pertambangan adalah Keseluruhan kaidah-kaidah hukum yang mengatur kewenangan negara dalam pengelolaan bahan galian (tambang) dan mengatur hubungan hukum antara negara dengan orang dan atau badan hukum dalam pengelolaan dan pemanfaatan bahan galian (tambang). ${ }^{3}$

Pasal 1 angka 1 Undang-Undang No 4 Tahun 2009 Tentang Perubahan Undang-Undang No 11 Tahun 1967 Tentang Pertambangan Mineral Dan Batubara (selanjutnya disebut UU Minerba) mengartikan pertambangan sebagai sebagian atau seluruh tahapan kegiatan dalam rangka penelitian,pengelolaan dan pengusahaan mineral atau batubara yang meliputipenyelidikan umum, eksplorasi, studi kelayakan,

1 I Gusti Ngurah Anom. “Efektifitas Peraturan Daerah Kabupaten Karangasem Nomor 17 Tahun 2012 Terhadap Pertambangan Galian Golongan C Di Desa Pempatan Kecamatan Rendang Kabupaten Karangasem." Jurnal Bakti Saraswati 6, no. 1 (2017): 73-82

2 Dwi Haryadi, Pengantar Hukum Pertambangan Mineral Dan Batubara, (Balinijuk, UBB Press, 2017), 21

3 Salim, Hukum Pertambangan Di Indonesia, (Jakarta, PT. Raja Grafindo Persada, 2006), 7 
konstruksi, penambangan, pengolahan dan pemurnian, pengangkutan dan penjualan, serta kegiatan pascatambang. ${ }^{4}$

Aktivitas usaha pertambangan tidak jauh berbeda dengan pengertian pertambangan yang menjelaskan aktivitas pertambangan dari awal sampai pasca tambang pada pertambangan galian golongan $\mathrm{C}$ menggunakan bahan galian, berdasarkan Pasal 2 PP Nomor 24 Tahun 2012 Tentang Perubahan PP Nomor 23 Tahun 2010 tentang Pelaksanaan Kegiatan Usaha Pertambangan Minerba, ditentukan 5 penggolongan komuditas tambang, meliputi: Mineral Radioaktif, Mineral Logam, Mineral Bukan Logam, Batuan, dan Batu Bara.Penggolongan dan pembagian tersebut suatu saat bisa saja berubah, sesuai dengan perkembangan ilmu pengetahuan dan teknologi. Tidak menuntup kemungkinan ada hasil riset yang menemukan jenis logam baru atau arena aktivitas geologi yang menyebabkan munculnya mineral baru yang bermanfaat dan dapat dieksploitasi. Berdasarkan pemaparan sebelumnya melihat kondisi golongan komoditas pertambangan yang berada di kabupaten Karangasem yakni pasir dan bebatuan yang sangat diperlukan untuk pembangunan sarana fisik seperti pembangunan gedung, jembatan untuk jalan dan pada kegiatan industri serta pembangunan fisik yang berkonstruksi berat. Maka penting adanya pelaksanaan peraturan sebagaimana diatur dalam UU Minerba dan PP Nomor 24 Tahun 2012 dalam pelaksanaan usaha pertambangan di kabupaten Karangasem.

Pertambangan Galian C di Pulau Bali atau yang lebih tepatnya di Kabupaten Karangasem dimulai sejak tahun 1990-an yang merupakan material letusan Gunung Agung pada tahun 1963. Kegiatan Usaha Pertambanganmerupakan kegiatan dalam rangka pengusahaan mineral atau batubara yang meliputi tahapan kegiatan penyelidikan umum, eksplorasi, studi kelayakan, konstruksi, penambangan, pengolahan dan pemurnian, pengangkutan dan penjualan, serta pascatambang. Pada Kabupaten Karangasem, salah satu daerah sebagai daerah galian pasir adalah Desa Adat Badeg yang terletak di Desa Sebudi Kecamatan Kabupaten Karangasem.Kualitas pasir yang dimiliki oleh Desa Adat dikenal secara luas sebagai pasir dan batu berkualitas tinggi terutama untuk pembangunan fisik.

Di Desa Adat Badeg Desa Sebudi Kecamatan Selat Kabupaten Karangasem, sebagian masyarakat lokal melakukan penambangan pasir di tanah pribadi yang disewa yang berlokasi di daerah perbukitan dengan menggunakan alat-alat yang sederhana dan teknologi yang tidak begitu canggih, seperti skopdibantu dengan alat muat keranjang rotan. Kegiatan penambangan pasir tersebut telah berlangsung selama 20 Tahun dan penguasaannya terjadi secara alamiah, pengembangan pertambangan yang berada di Desa Adat Badeg secara tidak langsung dapat memberikan lapangan pekerjaan bagi masyarakat dan dapat mengurangi pengangguran pada penduduk sekitaran wilayah tersebut, akan tetapi penambang pasir tersebut dalam melakukan

4 Albert F Sembiring. “Implementasi Pemberian Izin Usaha Galian Golongan C Sesuai Dengan Peraturan Bupati Nomor 11 Tahun 2001Di Kecamatan Tanah Jawa Kabupaten Simalungun." Skripsi. (2017) http://repositori.usu.ac.id 
usahanya seharusnya wajib memiliki izin Usaha Pertambangan Rakyat sebagaimana di tegaskan dalam Pasal 1 ayat (10) UU Minerba.

Kegiatan usaha pertambangan di Desa Adat Badeg, warga desa dapat menggunakan tanah milik pribadi ataupun milik desa yang diperoleh dari metinin. Metinin merupakan tanah druwe desa yang diberikan kepada setiap warga masyarakat untuk mengelolah tanahnya dalam kegiatan apapun, asalkan tanah tersebut tidak dijual. Menurut ketentuan adat yang berlaku di wilayah Desa Adat Badeg, tanah yang diperoleh dari metinin tidak boleh di jual, Oleh karena tanah metinin tersebut maka seluruh masyarakat berhak untuk melakukan kegiatan usaha pertambangan galian $\mathrm{C}$ dan mengelolah usaha yang dimiliki namun tak terlepas dari kewajiban-kewajiban yang harus dipatuhi oleh masyarakat desa yang melakukan usaha tersebut.Melihat masalah yang dipaparkan diatas maka penelitian ini mengangkat judul Desa Adat Sebagai Pelaku Usaha Pertambangan Bahan Galian Golongan C.

\subsection{Rumusan Masalah}

Berdasarkan uraian pada latar belakang diatas, maka dapat ditarikdua rumusan masalah sebagai berikut:

1. Apakah desa adat memiliki legalitas untuk bertindak sebagai pelaku usaha pertambangan bahan galian $\mathrm{C}$ di atas tanah druwe Desa?

2. Bagaimanakah kedudukan hukum Desa Adat Badeg dalam Kaitannya dengan pertambangan Bahan Galian C di atas tanah druwe Desa?

\subsection{Tujuan Penulisan}

Adapun Tujuan dari penulisan ini ialah, untuk mengetahui dan menganalisis tentang legalitas dari Desa Adat untuk bertingkah sebagai pelaku usaha pertambangan bahan galian $\mathrm{C}$ di atas tanah druwe Desa dan untuk mengetahui dan menganalisis tentang kedudukan hukum dari Desa Adat Badeg dalam kaliannya dengan pertambangan bahan galian $\mathrm{C}$ di atas tanah druwe Desa.

\section{Metode Penelitian}

Penulisan artikel ini menggunakan penelitian socio-legal merupakan sebuah studi penelitian yang melihat hukum melalui penggabungan antara analisa normatif dan pendekatan ilmu non-hukum. Banakar dan Travers, menyebutkan pendekatan sosiolegalmerupakan pendekatan interdisipliner. ${ }^{5}$ Penelitian yang dilakukan dengan menggunakan analisa normatif dan empiris. Penelitian yang dilakukan secara sosio-legal bertujuan untuk mengidentifikasi hukum sebagai institusi sosial yang riil dan fungsional dalam sistem kehidupan yang nyata dan menekankan cara memperoleh pengetahuan hukum secara empiris dengan terjun langsung ke obyek penelitian yaitu mengetahui bagaimana keadaan lapangan menegenai usaha pertambangan galian $\mathrm{C}$ di Kabupaten Karangasem khususnya pada Desa Adat Badeg.

Penelitian dengan analisa hukum normatifpenelitian hukum yang dilakukan dengan cara meneliti bahan pustaka atau data sekunder belaka yang bermula dari das

5 Herlambang P. Wiratraman. "Penelitian Sosio-Legal Dan Konsekuensi Metodologisnya." Center of Human Rights Law Studies (HRLS) Fakultas Hukum Universitas Airlangga. (2008) 
solen (law in books) menuju das sein (law in actions), dibangun di atas dasar peta konseptual rasional-konsisten-interpretatif yang mengandung unsur-unsur rasionalisme, positivisme hukum, a priori, analisa, deduksi, koherensi, interpretatif, data sekunder, kepustakaan dan kualitatif. ${ }^{6}$ Penelitian dengan analisa empiris yaitu penelitian hukum yang tidak saja dari aspek normatif tetapi dikaji tentang bagaimana pengimplementasiannya di masyarakat. ${ }^{7}$ Penelitian hukum empiris menganalisa data sekunder dengan analisa normatifdengan objek kajian norma hukum dan mempertahankan pakem kritis dari keilmuan-keilmuan hukum sebagai ilmu yang sui generis. $^{8}$

Bahan yang digunakan didasarkan pada analisis terhadap bahan-bahan kepustakaan sebagai sumber data, beberapa asas hukum serta peraturan perundangundangan(statute approach) dengan sumber hukum berupa buku-buku, artikel jurnal dan peraturan perundang-undangan, sedangkan data primer yang bertitik tolak, yakni data yang diperoleh langsung dari masyarakat sebagai sumber pertama dengan melalui penelitian lapangan berupa wawancara, disamping itu, penelitian ini sifatnya menggambarkan keseluruhan keadaan objek penelitian yang kemudian menjawab permasalahan dalam penelitian. ${ }^{9}$

\section{Hasil dan Pembahasan}

3.1. Legalitas Desa adat bertindak sebagai pelaku usaha pertambangan bahan galian C di atas tanah druwe Desa

Berdasarkan pelaksanaan tugasnya yang telah ditetapkan Pemerintah Provinsi Bali memberikan kewenangan kepada Desa Adat sebagai entitas negara yang sangat dekat atau mengetahui daerahnya.Kewenangan yang dapat dilaksanakan Desa Adat yang berada di Bali dalam menjalankan dan melaksanakan kebijakan dilingkungan wilayahnya, kemudian dapat dilihat dalam Peraturan Daerah Provinsi Bali Nomor 4 Tahun 2019 tentang Desa Adat di Bali yang selanjutnya disebut Perda Provinsi Bali tentang Desa Adat di Bali. Desa Adat adalah kesatuan masyarakat hukum adat di Bali yang memiliki wilayah, kedudukan, susunan asli, hak-hak tradisional, harta kekayaan sendiri, tradisi, tata krama pergaulan hidup masyarakat secara turun temurun dalam ikatan tempat suci (kahyangan tiga atau kahyangan desa), tugas dan kewenangan serta hak mengatur dan mengurus rumah tangganya sendiri, sesuai yang tercantum dalam Pasal 1 angka (8) Perda Provinsi Bali tentang Desa Adat di Bali.

Desa Adat yang telah ditetapkan sebagai subyek hukum dalam sistem pemerintahan sehingga Desa Adat yang berada di Bali dapat menjadi penyelenggara urusan pemerintahan dan kepentingan masyarakat setempat pada sistem pemerintahan, kemudian lebih spesifik membahas Desa Adat yang ada di Bali terdapat Peraturan Daerah mengenai eksistensi keberadaan desa adat itu sendiri. Kewenangan Desa Adat berdasarkan hak asal usul meliputi:

6 Zulfadli Barus. "Analisis Filosofis Tentang Peta Konseptual Penelitian Hukum Normatif dan Penelitian Hukum Sosiologis." Jurnal Fakultas Hukum Veteran Jakarta 13, no.2 (2013):307-318

7 Dr. Jonaedi Efendi, S.H.I., M.H dan Prof. Dr. Johnny Ibrahim, S.H., S.E., M.M., M.Hum, Metode Penelitian Hukum: Normatif Dan Empiris, (Jakarta,Prenada Media, 2018), 149

8 Eunike Syalom E. Pandey. "Kajian Yuridis Hak-Hak Atas Tanah Menurut Undang-Undang Nomor 5 Tahun 1960 Tentang Peraturan Dasar Pokok-Pokok Agraria." Lex Et Societatis 7, no.10 (2019)

9 Ronny Hanitijo Soemitro, Metodologi dan Jurimetri, (Jakarta, Ghalia Indonesia, 1990), 10 
a. Pembentukan Awig-Awig, Pararem, dan peraturan adat lainnya;

b. Turut serta dalam penentuan keputusan dan pelaksanaan pembangunan yang ada di Wewidangan Desa Adat;

c. Penetapan Anggaran Pendapatan dan Belanja Desa Adat;

d. Pengelolaan Padruwen Desa Adat;

e. Penetapan perencanaan pembangunan Desa Adat;

f. Pengembangan kehidupan hukum adat sesuai dengan asas Bali Mawacara dan Desa Mawacara;

g. Pelaksanaan pemerintahan berdasarkan susunan asli;

h. Pengelolaan Wewidangan dan tanah Padruwen Desa Adat;

i. Penetapan sistem organisasi dan pranata hukum adat;

j. Pemeliharaan ketenteraman dan ketertiban Krama di Desa Adat;

k. Penyelesaian perkara adat/wicara berdasarkan hukum adat;

1. Pengembangan dan pelestarian nilai adat, agama, tradisi, seni dan budaya serta kearifan lokal; dan

m. Penyelenggaraan sidang perdamaian perkara adat/wicara Adat yang bersifat keperdataan

Sesuai ketentuan yang tertuang pada Pasal 24 Perda Provinsi Bali tentang Desa Adat di Bali, adanya kewenangan yang telah diatur dalam peraturan daerah tersebut kemudian menjadikan desa adat sebagai pemerintah yang berkekuatan hukum.Kegiatan usaha pertambangan galian $\mathrm{C}$ di Kabupaten Karangasem, apabila dilihat dari poin (f) dan (h), menegaskan bahwa kegiatan usaha desa adat berhak untuk mengelola tanah desa adat wilayahnya untuk dimanfaatkan sebaik-baiknya dan tidak menyimpang dengan kesamaan hukum adat yang berlaku di Bali maupun hanya di Desa Adat setempat baik yang tertulis maupun tidak tertulis.Undang-undang Nomor 8 Tahun 1999 Tentang Perlindungan Konsumen yang selanjutnya disebut UU Perlindungan Konsumen, yang kaitannya dapat dilihat dalam pasal 1 angka (3) UU Perlindungan Konsumen menyatakan bahwa Pelaku usaha adalah setiap orang perseorangan atau badan usaha, baik yang berbentuk maupun bukan badan hukum yang didirikan dan berkedudukan atau melakukan kegiatan dalam wilayah hukum negara, baik sendiri maupun bersamasama melalui perjanjian penyelenggaraan kegiatan usaha dalam berbagai bidang ekonomi.Berdasarkan pengertian diatas, merujuk padapasal 35 UU Minerba menyatakan bahwa yang dapat melakukan usaha pertambangan galian $\mathrm{C}$, yaitu dalam bentuk:

1. Izin Usaha Pertambang.

2. Izin Pertambangan Rakyat.

3. Izin Usaha Pertambangan Khusus.

Beranjak dari ketentuan di atas dan selanjutnya disesuaikan dengan keadaan lapangan, pertambangan galian $C$ yang berada di Desa Adat Badeg, merupakan izin usaha pertambangan atau yang disebut IUP dan juga merupakan usaha pertambangan rakyat atau yang disebut IPR disebabkanpengelolaan usaha pertambangan galian $\mathrm{C}$ dapat dikatakan sebagai IUP karena memegang izin usaha pertambangan eksplorasi dan memegang izin usaha pertambangan operasi, sedangkan dapat dikatakan sebagai IPR dikarenakan pertambangan tersebut dilakukan hanya dapat dilakukan oleh 
masyrakat setempat dan sekaligus pemegang kuasa atas pertambangan tersebut serta tetap mengelola lingkungan hidup setempat bersama dengan Pemerintah Daerah.

Bahan galian merupakan unsur-unsur kimia mineral-mineral, bijih-bijih dan segala macam batuan termasuk batu-batu mulia yang merupakan endapan-endapan alam. Berdasarkan PP Nomor 24 Tahun 2012 pada pasal 2, ditentukan 5 golongan komuditas tambang, meliputi: Mineral Radioaktif berupa uranium; Mineral Logam berupa emas, tembaga, perak, seng, timah, besi dan aluminium; Mineral Bukan Logam berupa intan, asbes, belerang, kaolin, zircon dan tawas; Batuan berupa marmer, granit, tanah liat, batu apung, dan giok; dan Batu Bara. ${ }^{10}$ Kegiatan usaha pertambangan yang khususnya dilakukan di Desa Adat Badeg Karangasem menggunakan bahan galian berupa batuan, tercantum dalam pasal 1 angka 7 Peraturan Daerah Kabupaten Karangasem Nomor 13 Tahun 2012 Tentang Pengelolaan Usaha Pertambangan Batuan atau yang selanjutnya disebut Perda Kabupaten Karangasem Nomor 13 Tahun 2012 Tentang Pengelolaan Usaha Pertambangan Batuanmenyatakan bahwa mineral selain mineral radioaktif, mineral logam dan mineral bukan logam disebut dengan batuan.

Melalui wawancara dengan Bendesa Adat Badeg, Bapak Gusti Lanang Budiartha menyatakan bahwa pertambangan galian $\mathrm{C}$ yang dilakukan oleh Desa Adat itu sendiri, pemegang kuasa atas pertambangan galian $\mathrm{C}$ adalah masyarkat setempat yang telah mendapat izin usaha pertambangan melalui pemerintah daerah. Adanya Perda Kabupaten Karangasem Nomor 13 Tahun 2012 Tentang Pengelolaan Usaha Pertambangan Batuan dan mendasar pada Pasal 1 angka 35 dan Pasal 62 Perda Provinsi Bali Tentang Desa Adat di Bali mengenai Baga Utsaha Padruwen Desa Adat yang selanjutnya disingkat BUPDA adalah unit usaha milik Desa Adat yang melaksanakan kegiatan usaha di bidang ekonomi riil, jasa, dan/atau pelayanan umum, kecuali usaha di bidang keuangan, yang diselenggarakan berdasarkan hukum adat serta dikelola dengan tata kelola modern untuk meningkatkan kesejahteraan dan kemandirian Krama Desa Adat dan berhak untuk melakukan usaha khususnya sebagai masyarakat sekitar pertambangan galian C maka Desa Adat itu sendiri berhak melakukan kegiatan usaha pertambangan galian $\mathrm{C}$.

\subsection{Kedudukan Hukum Desa Adat Badeg dalam Kaitannya dengan pertambangan Bahan Galian C di atas tanah Druwe Desa}

Tanah Druwe Desa adalah tanah adat yang oleh beberapa pihak dikualifikasikan sebagai tanah ulayat merupakan tanah bersama yang dikuasai dan dimiliki oleh desa adat secara komunal. Lazimnya tanah druwe yang oleh beberapa pihak dikualifikasikan sebagai tanah ulayat menurut Undang-Undang Nomor 5 Tahun 1960 Tentang PokokPokok Agraria (UUPA) selanjutnya disebut dengan tanah adat. ${ }^{11}$

Dengan adanya tanah druwe desa, sangat menguntungkan bagi masyarakat sekitar karena memiliki fungsi keagamaan atau religius yang terkait dengan ayahanayahan turut menyangga pembangunan di pura yang terdapat diwilayah desa adat; sosial, berpartisipasi dalam pembangunan yang bersifat sosial kemasyarakatan; ekonomis yaitu sebagaimana tanah adat tersebut juga diupayakan memberikan

${ }^{10}$ Dwi Haryadi, Op.Cit, 22

11 I Gusti Agung Mas Rwa Jayantiari. “Tinjauan Yuridis Pengaturan Tanah Druwe Desa Di Bali (Aspek Hukum Perlindungan Masyarakat Adat Atas Tanah)." Jurnal LingkunganEPembangunan 1, no.1 (2017):33-39 
keuntungan ekonomi bagi pemilik dan atau yang menguasainya. ${ }^{12}$ Walaupun tanah druwe desa memiliki keuntungan bagi masyarakatnya terutama keuntungan dibidang ekonomi, bahwa pengelolaan Padruwen Desa Adat dilaksanakan berdasarkan asas dan awig-awig Desa Adat untuk kesejahteraan Krama Desa, maka pengeolahaan tanah druwe desa adat sesuai dengan awig-awig yang berlaku dan tak terlepas atas kewajibankewajiban yang harus dipenuhi, sesuai dengan ketentuan yang berlaku seperti memberikan ayah-ayahan yang berupa tenaga, yaitu menyediakan dirinya untuk ngayah atau berkorban ke desa pakraman dan ngayah ke Pura/Kahyanagan Desa seperti gotong royong membersihkan pura, memperbaiki pura hingga menyelenggarakan upacara keagamaan di dalamnya dan material, yaitu menyediakan uang atau materi lainnya demi kepentingan desa adat sebagai wujud fungsional tanah druwe desa dibidang religious, membayar sumbangan punia kepada desa adat sebagai wujud tanah druwe desa dibidang ekonomi.

Pada Desa Adat Badeg khususnya, melalui wawancara dengan Bendesa Adat Badeg, tanah druwe desa yang berada di wilayah desa adat itu sendiri diperoleh dengan cara metinin. Tanah adat yang di peroleh dari hasil metinin, sebagaimana tanah metinin tersebut dikelola oleh masyarakat Desa Adat sebagai sektor perekonomian dengan adanya pertambangan galian C. Masyarakat Desa Adat Badeg sendiri yang memperoleh tanah metinin sendiri berhak mengelola pertambangan itu sendiri sesuai dengan ketentuan adat yang berlaku seperti luas wilayah tanah yang maksimal memiliki luas tanah sebesar satu hektar, selain hal tersebut juga mendaftarkan usahanya ke Pemerintah Daerah agar mendapatkan izin usaha pertambangan atau yang kerap disebut IUP dan melaksanakan kewajiban adat dengan membayarkan 20\% dari keuntungan yang didapat dari hasil usaha pertambangan galian $\mathrm{C}$ tersebut.

Desa Adat Badeg sendiri melakukan usaha pertambangan berupa bahan yang berasal dari batuan, yang sebagaian besar pekerja pada sector pertambangan galian C di Desa Adat Badeg adalah masyarakat adat setempat, dan secara struktural kepemilikan tanah merupakan tanah metinin dari Desa Adat Badeg ke masing-masing warganya dengan menjalankan pengelolahaan usaha sesuai dengan ketentuan adat yang berlaku, sampai saat ini belum adanya hambatan yang terjadi saat pengoperasionalan dan pelaksanakan Pertambangan Galian C di Desa Adat Badeg dan kegiatan usaha yang dilakukan oleh Desa Adat Badeg tidak terlepas dari aturan hukum yang berlaku diwilayah adat setempat.

\section{Kesimpulan}

Berdasarkan uraian diatas, maka dapat disimpulkan mengenai Desa Adat Sebagai Pelaku Usaha Pertambangan Golongan Galian C ialah, Kewenangan Desa adat Badeg penyelenggaran kegiatan usaha pertambangan yang menyatakan desa adat dapat melakukan usahanya dalam bentuk IUP dan IPR dan sekaligus pemegang kuasa atas pertambangan tersebut serta tetap mengelola lingkungan hidup setempat bersama dengan Pemerintah Daerah,yang diselenggarakan berdasarkan hukum adat serta dikelola dengan tata kelola modern sebagai masyarakat sekitar pertambangan galian $\mathrm{C}$ maka Desa Adat itu sendiri berhak melakukan kegiatan usaha pertambangan galian C. Melalui wawancara dengan Bendesa Adat Badeg, tanah druwe desa yang berada diwilayah desa adat itu sendiri diperoleh dengan cara metinin, merupakan

12 Dewa Gde Rudy. "Perjanian Sewa Menyewa Tanah Pekarangan Desa (PKD) Berdasarkan Peraturan Daerah Propinsi Bali Nomor 3 Tahun 2001 Tentang Desa Pakraman." Jurnal Notariil 2, no.2 (2017.):149-159 
pengeolahaan tanah druwe desa adat sesuai dengan awig-awig yang berlaku dan tak terlepas atas kewajiban-kewajiban yang harus dipenuhi, sesuai dengan ketentuan yang berlaku seperti memberikan ayah-ayahan yang berupa tenaga, selain itu juga wajib membayarkan $20 \%$ dari keuntungan yang didapat dari hasil usaha pertambangan galian $\mathrm{C}$ tersebut, maka sesuatu kegiatan usaha yang dilakukan oleh Desa Adat Badeg tidak terlepas dari aturan hukum yang berlaku diwilayah adat setempat.

\section{Daftar Pustaka}

Buku

Dwi Haryadi, Pengantar Hukum Pertambangan Mineral Dan Batubara, (Balinijuk, UBB Press, 2017).

Dr. Jonaedi Efendi, S.H.I., M.H dan Prof. Dr. Johnny Ibrahim, S.H., S.E., M.M., M.Hum, Metode Penelitian Hukum: Normatif Dan Empiris, (Jakarta,Prenada Media, 2018).

Ronny Hanitijo Soemitro, Metodologi dan Jurimetri, (Jakarta, Ghalia Indonesia, 1990).

Salim, Hukum Pertambangan Di Indonesia, (Jakarta, PT. Raja Grafindo Persada, 2006).

\section{Jurnal}

Albert F Sembiring. “Implementasi Pemberian Izin Usaha Galian Golongan C Sesuai Dengan Peraturan Bupati Nomor 11 Tahun 2001Di Kecamatan Tanah Jawa Kabupaten Simalungun." Skripsi. (2017) http://repositori.usu.ac.id

Dewa Gde Rudy. "Perjanian Sewa Menyewa Tanah Pekarangan Desa (PKD) Berdasarkan Peraturan Daerah Propinsi Bali Nomor 3 Tahun 2001 Tentang Desa Pakraman." Jurnal Notariil 2, no.2 (2017):149-159

Eunike Syalom E. Pandey. "Kajian Yuridis Hak-Hak Atas Tanah Menurut UndangUndang Nomor 5 Tahun 1960 Tentang Peraturan Dasar Pokok-Pokok Agraria." Lex Et Societatis 7, no.10 (2019)

Herlambang P. Wiratraman. "Penelitian Sosio-Legal Dan Konsekuensi Metodologisnya." Center of Human Rights Law Studies (HRLS) Fakultas Hukum Universitas Airlangga. (2008)

I Gusti Agung Mas Rwa Jayantiari. “Tinjauan Yuridis Pengaturan Tanah Druwe Desa Di Bali (Aspek Hukum Perlindungan Masyarakat Adat Atas Tanah)." Jurnal LingkunganEPembangunan 1, no.1 (2017):33-39

I Gusti Ngurah Anom. "Efektifitas Peraturan Daerah Kabupaten Karangasem Nomor 17 Tahun 2012 Terhadap Pertambangan Galian Golongan C Di Desa Pempatan Kecamatan Rendang Kabupaten Karangasem." Jurnal Bakti Saraswati 6, no. 1 (2017): 73-82

Zulfadli Barus. “Analisis Filosofis Tentang Peta Konseptual Penelitian Hukum Normatif dan Penelitian Hukum Sosiologis." Jurnal Fakultas Hukum Veteran Jakarta 13, no.2 (2013):307-318

\section{Peraturan Perundang-Undangan}

Undang-Undang Republik Indonesia Nomor 8 Tahun 1999 Tentang Perlindungan Konsumen, Lembaran Negara Republik Indonesia Tahun1999 No.22, Tambahan Lembaran Negara Republik Indonesia No.3821.

Undang-Undang Republik IndonesiaNomor 4 Tahun 2009 TentangPertambangan Mineral Dan Batubara, Lembaran Negara Republik Indonesia Tahun2009 No.4, Tambahan Lembaran Negara Republik Indonesia No.4959. 
Peraturan Pemerintah Republik Indonesia Nomor 24 Tahun 2012 Tentang Perubahan Atas Peraturan Pemerintah Nomor 23 Tahun 2010 Tentang Pelaksanaan Kegiatan Usaha Pertambangan Mineral Dan Batubara, Lembaran Negara Republik Indonesia Tahun 2012 No.45, Tambahan Lembaran Negara Republik Indonesia No. 5282.

Peraturan Daerah Provinsi Bali Nomor 4 Tahun 2019 tentang Desa Adat di Bali, Lembaran Daerah Provinsi Bali Tahun 2019 No.4, Tambahan Lembaran Daerah Provinsi Bali No. 4.

Peraturan Daerah Kabupaten KarangasemNomor 13 Tahun 2012TentangPengelolaan Usaha Pertambangan Batuan, Lembaran Daerah Kabupaten Karangasem Tahun 2012 No.13, Tambahan Lembaran Daerah Kabupaten Karangasem No. 13. 